\title{
The crime reducing effect of education
}

Citation for published version (APA):

Machin, S., Marie, O., \& Vujic, S. (2010). The crime reducing effect of education. Researchcentrum voor Onderwijs en Arbeidsmarkt, Faculteit der Economische Wetenschappen. ROA Research Memoranda No. 13 https://doi.org/10.26481/umaror.2010013

Document status and date:

Published: 01/01/2010

DOI:

10.26481/umaror.2010013

Document Version:

Publisher's PDF, also known as Version of record

\section{Please check the document version of this publication:}

- A submitted manuscript is the version of the article upon submission and before peer-review. There can be important differences between the submitted version and the official published version of record.

People interested in the research are advised to contact the author for the final version of the publication, or visit the DOI to the publisher's website.

- The final author version and the galley proof are versions of the publication after peer review.

- The final published version features the final layout of the paper including the volume, issue and page numbers.

Link to publication

\footnotetext{
General rights rights.

- You may freely distribute the URL identifying the publication in the public portal. please follow below link for the End User Agreement:

www.umlib.nl/taverne-license

Take down policy

If you believe that this document breaches copyright please contact us at:

repository@maastrichtuniversity.nl

providing details and we will investigate your claim.
}

Copyright and moral rights for the publications made accessible in the public portal are retained by the authors and/or other copyright owners and it is a condition of accessing publications that users recognise and abide by the legal requirements associated with these

- Users may download and print one copy of any publication from the public portal for the purpose of private study or research.

- You may not further distribute the material or use it for any profit-making activity or commercial gain

If the publication is distributed under the terms of Article $25 \mathrm{fa}$ of the Dutch Copyright Act, indicated by the "Taverne" license above, 


\section{The Crime Reducing Effect of Education}

Stephen Machin

Olivier Marie

Sunčica Vujić

\section{ROA Research Memorandum}

ROA-RM-2010/13

Research Centre for Education and the Labour Market Maastricht University

P.O. Box 616,6200 MD Maastricht, The Netherlands

$\mathrm{T}+31433883647 \mathrm{~F}+31433884914$

secretary-roa-sbe@maastrichtuniversity.nl www.roa.nl 


\title{
The Crime Reducing Effect of Education
}

\author{
Stephen Machin \\ Olivier Marie \\ Sunčica Vujić
}

ROA-RM-2010/13*

October 2010

Research Centre for Education and the Labour Market

Maastricht University

P.O. Box 616, 6200 MD Maastricht, The Netherlands

$\mathrm{T}+31433883647 \mathrm{~F}+31433884914$

secretary-roa-sbe@maastrichtuniversity.nl

www.roa.nl

\footnotetext{
* The ROA Research Memorandum Series was created in order to make research results available for discussion, before those results are submitted for publication in journals.
} 


\title{
Abstract
}

\section{The Crime Reducing Effect of Education**}

In this paper, we study the crime reducing potential of education, presenting causal statistical estimates based upon a law that changed the compulsory school leaving age in England and Wales. We frame the analysis in a regression-discontinuity setting and uncover significant decreases in property crime from reductions in the proportion of people with no educational qualifications and increases in the age of leaving school that resulted from the change in the law. The findings show that improving education can yield significant social benefits and can be a key policy tool in the drive to reduce crime.

JEL classification: 12; K42.

Keywords: Crime; Education; School Leaving Age.

\author{
Stephen Machin \\ Department of Economics \\ University College London \\ Gower Street \\ London WC1E 6BT \\ United Kingdom \\ s.machin@ucl.ac.uk
}

\author{
Olivier Marie \\ ROA \\ Maastricht University \\ P.O. Box 616 \\ 6200 MD Maastricht \\ The Netherlands \\ o.marie@maastrichtuniversity.nl
}

\author{
Sunčica Vujić \\ Department of Management \\ London School of Economics \\ Houghton Street \\ London WC2A 2AE \\ United Kingdom \\ s.vujic@lse.ac.uk
}

\footnotetext{
** This is a heavily revised version of Machin, Marie and Vujić (2010). Machin and Vujić wish to thank the Economic and Social Research Council for funding under research grant RES-000-22-0568. Marie would like to thank the Executive Research Agency of the European Union for funding under the Marie Curie IEF grant number 252572. Useful comments were received from Brian Bell, Lance Lochner, two referees and participants in numerous seminars and conferences.
} 


\section{Introduction}

Crime reduction is high on the public policy agenda, not least because of the large economic and social benefits it brings. Indeed, research on the determinants of crime points in several directions as to how crime reduction can be facilitated. A relatively large body of research undertaken by social scientists considers the potential for expenditures on crime fighting resources (like increased police presence, or new crime fighting technologies), or on particular policies to combat crime. ${ }^{1}$ Other work focuses more on the characteristics of criminals and considers which characteristics are more connected to higher criminal participation. In this latter case, policies that affect these characteristics can, if implemented successfully, be used to counter crime.

In this paper, we focus on one such characteristic that has received some attention in the quantitative social science literature on the determinants of crime, namely education. In this literature, there is a (relatively small) body of work that attempts to establish a causal connection between crime and education (most notably the seminal paper of Lochner and Moretti, 2004) and a vast literature from various social science disciplines that does not. ${ }^{2}$ A drawback associated with almost all of this latter work is that it is difficult to ascertain whether the direction of causation flows from education to crime (and not the other way around). This, of course, matters if one wishes to consider appropriate policy responses to empirical findings.

\footnotetext{
${ }^{1}$ UK evidence on the crime-police relation (in the context of the July 2005 terror attacks that hit London) is presented in Draca, Machin and Witt (2010) and evidence of crime reduction from a specific policy (the Street Crime Initiative) appears in Machin and Marie (2010).

${ }^{2}$ Examples from the criminology literature include Farrington $(1986,2001)$ and from the education literature include Sabates $(2008,2009)$ and Sabates and Feinstein (2008). There is much less work by economists. See Lochner (2010) for a broader overview of the crime and education literature.
} 
Our focus is on empirically analysing the crime reducing potential of education and we present causal statistical evidence based upon a law that changed the compulsory school leaving age in England and Wales. As the raising of the school leaving age generated sharp increases in education for those affected, we frame our analysis in a regression-discontinuity setting looking at birth cohorts just before and after the law change. We show that there were significant property crime reductions associated with the extra education people obtained (or were forced to obtain) from the raising of the school leaving age. The implications of these findings are clear. Not only do they show that improving the education levels and attainment of individuals who would otherwise be on the margins of crime participation can act as a key policy tool in the drive to reduce crime, but also that such educational improvements can yield sizable social benefits.

The rest of the paper is organised as follows. Section 2 offers a brief discussion of the theoretical background on the relationship between education and crime, describes the data sources used, shows some descriptive evidence on the association between crime and education and discusses the school leaving age reform we consider. Section 3 describes the empirical strategies we implement and presents the results, together with a calculation of the social benefits that follow from the estimated crime reducing effect of education. Concluding remarks are given in the last section of the paper.

\section{Crime Reducing Education Mechanisms, Data and Descriptive Analysis}

\section{Mechanisms Where Education Changes Can Impact on Crime}

There are number of theoretical reasons why education may have an effect on crime. From the existing socio-economic literature there are (at least) three main channels 
through which schooling might affect criminal participation: income effects, time availability, and patience or risk aversion. For most crimes, one would expect that these factors induce a negative effect of schooling on crime, although ultimately this is an empirical question. We briefly consider each of the three mechanisms in turn:

i) The income effect works through education increasing the returns to legitimate work and/or raising the opportunity costs of illegal behaviour (Lochner, 2004; Lochner and Moretti, 2004; Hjalmarsson, 2008). Empirical evidence supports the notion: for example, Grogger (1998) links crime to wages, concluding that youth offending behaviour is responsive to price incentives and that falling real wages may have been an important factor in rising youth crime during the 1970s and 1980s. Machin and Meghir (2004) look at cross-area changes in crime and the low wage labour market in England and Wales. They find that crime fell in areas where wage growth in the bottom $25^{\text {th }}$ percentile of the distribution was faster and conclude that "improvements in human capital accumulation through the education system or other means... enhancing individual labour market productivity... would be important ingredients in reducing crime."

Conversely, there is also some evidence that education can also increase the earnings from crime as certain skills acquired in school may be inappropriately used for criminal activities. Levitt and Lochner (2001) find that males with higher scores on mechanical information tests had increased offence rates. Lochner (2004) also estimates that across cohorts, increases in average education are associated with $11 \%$ increase in white-collar arrest rates (although this estimated effect is not statistically significant).

ii) Time spent in education may also be important for teenagers in terms of limiting the time available for participating in criminal activity. This 'self-incapacitation' effect was 
documented by Tauchen et al. (1994) who found that time spent at school (and work) during a year is negatively correlated to the probability of arrest that year. Hjalmarsson (2008) looked at the opposite relationship, studying the impact of being arrested and incarcerated before finishing school on probability of graduating high school. Her results suggest that the more times you are caught committing crime and the amount of time spent in prison both greatly increase the likelihood of becoming a high school dropout.

As these still may be endogenous decisions, Jacob and Lefgren (2003) instrument days off school with exogenous teacher training days and Luallen (2006) uses unexpected school closings driven by teacher strikes as an instrument for student absence from school. Both papers find important incapacitation effects of education on criminal participation. However, they also report that violent offences increase while school is in session, a finding that is attributed to a concentration effect. ${ }^{3}$ Anderson (2009) also reports US evidence, based on minimum high school dropout ages that vary across states, in line with the notion that keeping youth in school decreases arrest rates.

iii) Education may also influence crime through its effect on patience and risk aversion (Lochner and Moretti, 2004). Here, future returns from any activity are discounted according to one's patience in waiting for them. Thus, individuals with a lot of patience have low discount rates and value future earnings more highly as compared to those with high discount rates. Oreopoulos (2007) summarizes a sample of studies from the psychological and neurological literature, concluding that young people who drop out of school tend to be myopic and more focussed on immediate costs from schooling (stress from taking tests, uninteresting curricula, foregone earnings, etc.), rather than on future

\footnotetext{
${ }^{3}$ This is the geographical proximity of a large number of youths - in the educational establishment - which may result in increasing the probability of violent encounters.
} 
gains from an additional year of schooling. This line of literature also suggests that adolescents lack abstract reasoning skills and are more predisposed to risky behaviour. Education can increase patience, which reduces the discount rate of future earnings and hence reduces the propensity to commit crimes. Education may also increase risk aversion that, in turn, increases the weight given by individuals to a possible punishment and consequently reduces the likelihood of committing crimes.

\section{Data Description}

There are a number of pertinent data issues that we next need to discuss, as they are relevant in the context we study. First, there is the issue that crime measurement is different across data sources. Second, whilst some micro-data on crime does contain information on the characteristics of criminals, the majority does not. In the latter case, we need some means of matching crime data to education data.

Probably the most commonly used source of crime data in quantitative research is information on criminal offences recorded by the police. As not all of these are solved or cleared up, this type of data does not contain information on characteristics of the individuals committing these recorded offences. Unless these data are aggregated to some geographical level (like police force area) and matched to education data at this level, then it is not possible to use these data to study the empirical relationship between crime and education. Being realistic, such spatial aggregation does not offer much hope to credibly study the research question of interest in this paper.

The other main form of crime data available comes from those individuals who enter the criminal justice system after having been apprehended and charged for a crime. In England and Wales, the Offenders Index Database (OID) contains criminal history 
data for offenders convicted of standard list offences from 1963 onwards. ${ }^{4}$ The data (which are described in detail in Data Appendix A) are derived from the court appearances system and are updated quarterly. The Index was created purely for research and statistical analysis. Its main purpose is to provide full criminal history data on a randomly selected sample of offenders.

We have access to OID data on anonymous samples for offenders sentenced during four weeks each year. We also have the entire pre- and post-court appearance history of these individuals. However, there is no information on a defendant's education level in the OID and so the data needs to be aggregated to connect to education data from other sources. A big advantage (certainly relative to recorded offences data) is that some demographic characteristics are available in the OID, notably age and gender.

We therefore calculated offending rates (per 1000 population) using Office for National Statistics (ONS) population data by age cohort and year, separately for men and women. In doing so, criminal offences were also broadly categorised as property crimes (burglary and theft and handling stolen goods) and violent crimes (violence against the person and robbery). These offending rates can be matched to education data from other micro-data sources where education measures can be collapsed into age by year (by gender) cells.

We investigated several possible sources of data containing individual education characteristics to match to the OID. The three main candidates were: the Family Expenditure Survey (FES); the General Household Survey (GHS); and the Labour Force Survey (LFS). The best match turned out to be the GHS for several reasons. First, it

\footnotetext{
${ }^{4}$ Standard list offences are all indictable or triable offences, plus a few of the more serious summary offences.
} 
enables us to go further back in time, with a start year of 1972 with well defined education data, as compared to 1978 in the FES and 1979 (with some missing years as the original survey was only bi-annual) in the LFS. Starting earlier in the 1970s is important, to ensure we have data on young enough people before and after when the education reform we consider occurred. Second, we can consider two measures of education - age left school and whether individuals have no educational qualifications - in the GHS, whereas the FES only has information on age left full-time education and the LFS contains information on no qualifications (though not consistently in all years) and age left full-time education. Thirdly, as we are planning to look at the causal impact via a school leaving age law, the GHS has the more appropriate age left school measure whereas the other two data sources relate to school and non-school terminal age. Data Appendix A describes more fully how we matched the OID and GHS data for the main analysis in this paper. Our sample consists of people aged 18-40 born between 1946 and 1970 from OID and GHS data across the 1972 to 1996 time period.

Other data sources with information on crime activity do permit non-causal analyses to be undertaken. For example, Census micro-data in a number of countries does contain information on both incarceration (individuals who are in prison service establishments) and on individual education levels. ${ }^{5}$ However, in the UK context, only the 2001 Census has good enough data on individual education and so only permits a cross-sectional analysis. The British Crime Survey (BCS) also contains information on the respondent's education level and rudimentary self-reported information on criminal histories.

\footnotetext{
${ }^{5}$ Indeed, a large part of the US paper by Lochner and Moretti (2004) uses US Census data. Their major advantage is having several US Censuses when both imprisonment and education data were simultaneously available.
} 
For purposes of illustration, Table 1 uses these different data sources to show some non-causal regression estimates of the association between crime and education for 18-40 year-old men and women. Like other studies in the large literature in this area, they show a significant empirical negative correlation between crime and age left education and a positive association with no qualifications. This is true for the matched OID-GHS data in the upper panel (except for the no qualifications association for women), the 2001 Census data on imprisonment and no qualifications in the middle panel and the 2001/22007/8 British Crime Survey self-report data on ever being arrested or ever being in court as the defendant.

Of course, these are simply correlations and are not easy to interpret as there are many other confounding factors at play. For the cases of the cohort models, consider a simple least squares regression of a measure of offending for a particular age cohort $a$ in year $t\left(O_{a t}\right)$ with an education variable $\left(E_{a t}\right)$ as an explanatory variable and $X_{j a t}($ $j=1,2, \cdots, J$ ) being a set of other control variables:

$$
O_{a t}=\alpha_{0}+\alpha_{1} E_{a t}+\sum_{j=0}^{J} \lambda_{j} X_{j a t}+u_{a t}
$$

where $u_{a t}$ is an error term.

If unobserved characteristics of cohorts drive crime participation, but also education, then least squares estimates of $\alpha_{1}$ (like those given in Table 1) will be biased. This is a key issue to the extent that unobserved characteristics affecting schooling decisions may be correlated with unobservables influencing the decision to engage in crime. For example, $\alpha_{1}$ could be estimated to be negative, even if schooling has no causal effect on crime. This would be the case if individuals who have high criminal returns were likely to spend most of their time committing crime rather than work, 
regardless of their educational background. As long as education does not increase the returns to crime, these individuals are likely to drop out of further education. As a result, we might observe a negative correlation between education and crime even though there is no causal effect between the two. To implement a causal approach that is plausible requires an instrument for education, which is the issue we turn to next.

\section{The School Leaving Age Reform}

Identification of a causal education impact on crime is generated from a compulsory school leaving increase that affected 15 year-olds in England and Wales in the early 1970s. Like Lochner and Moretti's (2004) approach, which exploits changes in school leaving age laws across US states, we use the raising of the school leaving from age 15 to 16 that took force in England and Wales in September 1972 (thus affecting the cohort of children finishing school in 1973) as an instrumental variable in our empirical analysis. ${ }^{6}$

The raising of the school leaving age generates a discontinuity in education measures at the time when the reform was implemented. In the next section of the paper we will show results from empirical analysis of relationships between the law change and crime and education using instrumental variable and regression discontinuity methods. However, before moving on to this, we first illustrate discontinuities induced by the reform. Figure 1 uses GHS data to show the average age left school and the proportion

\footnotetext{
${ }^{6}$ There was an earlier increase in the compulsory school leaving age from 14 to 15 that took force in April 1947. This and (less frequently) the law we focus on here have been considered in a growing literature in labour and health economics. Harmon and Walker (1995) and Oreopoulos (2006) focus on the causal impact of education on earnings (see also Devereux and Hart's (2010) robust criticism of the Oreopoulos paper). Galindo-Rueda (2003), Chevalier (2004), and Chevalier et al. (2005) look at the effect of parental income on education of their children. Oreopoulos (2006), Doyle et al. (2007), and Lindeboom et al. (2009) examine the impact of education on health. We are the first to consider the school leaving age reforms in England and Wales to study the causal impact of education on crime. Of course, we do not have data on crime for young enough people before and after the 1947 increase and so can only consider the 1972 law.
} 
with no educational qualifications for men aged 18-40 who were born between 1950 and 1965. The vertical line in Figure 1 shows the timing of the law change. There is a very clear and marked fall in the proportion with no educational qualifications in the upper Figure and a sharp increase in the average school leaving age in the lower Figure. Evidently there was a big discontinuity in educational outcomes induced by the law change. The non-overlapping nature of the confidence intervals before and after the discontinuity in the Figure shows that the changes were clearly statistically significant. Figure 2 also shows a marked fall in the OID conviction rate for men leaving school after the school leaving reform. There is a very clear and distinct drop in the conviction rate at the discontinuity, after which convictions trend upwards. The existence of clear and significant discontinuities in both crime and education is highly suggestive of a causal impact, the issue and detail of which we next empirically explore.

\section{$\underline{\text { 3. Causal Estimates of the Crime-Education Relation }}$}

In this section of the paper, we present instrumental variable (IV) and regressiondiscontinuity (RD) based estimates of the relationship between crime and education. We begin with the IV estimates, move next to the RD estimates, show a series of robustness tests and last present some calculations of the social benefits of crime reduction induced by improved education.

\section{Instrumental Variable Estimates}

Identification of the causal effect of education on crime is achieved through inclusion in a first stage education regression of a dummy variable that records the exogenous change in the minimum school leaving age that occurred in England and 
Wales, as described above. We define a dummy variable (SLA) equal to one for individuals who entered their last compulsory school year in 1972 and later. The discontinuity is generated for the 1972 cohort who were the first to face a minimum school leaving age of 16 (SLA) when they left school in $1973 .{ }^{7}$

The relevant crime and education reduced forms are

$$
\begin{aligned}
& O_{a t}=\beta_{0}+\beta_{1} S L A_{a t}+\sum_{j=0}^{J} \phi_{j} X_{j a t}+v_{a t} \\
& E_{a t}=\delta_{0}+\delta_{1} S L A_{a t}+\sum_{j=0}^{J} \varphi_{j} X_{j a t}+v_{a t}
\end{aligned}
$$

The crime structural form therefore used to yield causal estimates is

$$
O_{a t}=\theta_{0}+\theta_{1} E_{a t}+\sum_{j=0}^{J} \sigma_{j} X_{j a t}+\varepsilon_{a t}
$$

where the IV estimate of the coefficient on the education variable in (3) is the ratio of the reduced form coefficients in (2), $\theta_{1}=\beta_{1} / \delta_{1}$.

In this framework, it is important whether the change in compulsory schooling age legislation acts as a valid instrument. A legitimate instrument for education in equation (3) is a variable that: (i) significantly explains part of the variation in education; and (ii) is not correlated with the unobservables that are correlated with both offending and education. Put alternatively, it is a variable that is a determinant of schooling that can legitimately be omitted from equation (1). Our estimates hinge on the notion that SLA fulfils these requirements. The first issue is a statistical one which, as shown below, is satisfied as SLA is a strong predictor of education. Regarding the second issue, changes in compulsory attendance laws have not historically been concerned by problems with

\footnotetext{
${ }^{7}$ In most years of the GHS we do not know month of birth. Therefore, in a similar way to Devereux and Hart (2010) in their analysis of the 1947 reform which was introduced in April 1947, where they code their reform variable equal to 0 for pre- 1933 birth cohorts, to 0.75 for the 1933 cohort and 1 to the post-1933 cohorts, we code SLA to 0.33 for the 1957 birth cohort (since the reform began on 1 September 1972).
} 
crime. To our knowledge, legislators enacting the laws did not act in response to concerns with juvenile delinquency, youth unemployment, or other factors related to crime, thus making schooling laws an appropriate instrument.

It also needs to be acknowledged that the variation induced by the instrument is local in nature, as it has an impact at the bottom of the education distribution and not at the top. This is because people near the top would have stayed on after the compulsory school leaving age anyway and the change would not affect them. Therefore, the effect that our empirical approach estimates is the local average treatment (LATE) effect among those who alter their treatment status because they react to the instrument. For this reason, we consider effects separately for the continuous age left school measure, but also more appropriately for the no qualifications variable.

\section{Baseline Estimates}

The first set of baseline estimates for total conviction rates are given in Table 2 . The Table shows four sets of estimates of the reduced and structural form crime and education models described in equations (2) and (3). Columns (1)-(5) respectively show the crime reduced form, education reduced form and crime structural form for the no qualifications and age left school variables from the GHS-OID 1972-96 cohort year data for men aged 18-40 who were born between 1946-70. Columns (6)-(10) do the same, but for a sample of $+/$ - four birth cohorts around the discontinuity point.

Both crime and education reduced forms show a strong and significant effect of the school leaving age increase. In column (1) there is a 4.7 percent point fall in the conviction rate in the years after the education reform, revealing a statistically significant crime reduced form. In columns (2) and (5), the same is true of education, with a 5.7 
percent fall in the proportion with no qualifications and an increase of almost a quarter of a year $(0.22)$ in the average school leaving age.

These significant crime and education effects combine into a significant causal impact of education on crime. Column (3) shows the IV estimate for the no qualifications variable. It is positive and strongly significant at 0.82 . Interestingly this is larger than the comparable non-causal, least squares estimate of 0.40 reported in the upper panel of Table 1. A strong crime reduction from education is also seen in the age left school specification in column (5) where a 10 percent increase in age left school lowers crime by 2.1 percent. $^{8}$ In this case, this is exactly the same as the least squares estimate in Table 1.

The fact that the IV estimates lie at or above comparable least squares estimates draws an interesting parallel with the literature on the causal effect of education on earnings where the same pattern seems to occur (see Card, 1999). It does not seem unreasonable to think that the same kind of mechanisms discussed in that literature, highlighting the fact that the IV estimates pick up a local average treatment effect on low education individuals, also apply in interpreting the crime-education results reported here.

\section{Discontinuity Sample}

As Figures 1 and 2 show, there are sharp crime and education discontinuities for cohorts affected by the school leaving age law. It therefore is natural to focus more on observations nearer to the discontinuity point. The specifications in columns (6) to (10) of Table 2 show results from focussing in on a window defined as $+/$ - four years around

\footnotetext{
${ }^{8}$ Table B1 in Appendix B shows results for women. The education reduced forms are, if anything, stronger for women, but the crime reduced forms are imprecisely determined and therefore so is the IV estimate. This imprecision in estimates is not surprising given the very low female offending rates, especially amongst the older women in our age 18-40 cohorts, seen in the data.
} 
the treated birth cohort at the discontinuity (i.e. those individuals born between 1953 and 1961).

The main substantive change, which is probably not surprising given the narrowing of the cohort window, is that the estimated reduced form coefficients rise in absolute magnitude. This is the case in both the crime and education reduced forms such that the IV estimates remain similar. For the no qualifications and age left school specifications the IV estimate is strongly significant, identifying a causal crime reducing effect of education.

\section{Inverse Distance Weighting}

The second way we hone in more on the discontinuity is to note that the policy treatment induced by the law change is binding for the cohort right near the discontinuity in September 1957. We have thus also generated inverse distance weighted estimates where we place more weight on those observations nearer to the discontinuity point and less as they are further away. ${ }^{9}$ We do this to ensure that identification predominantly comes from variation close to the discontinuity, weighting by $1 / d$ where $d$ is distance in birth years from the discontinuity.

The inverse distance weighted (IDW) results are given in Table 3, which is of the same form as Table 2 . The pattern of results is qualitatively the same as in Table 2 although the coefficient on the school leaving age dummy variable tends to increase in magnitude (in absolute terms) in the full sample and in the discontinuity sample. The IDW IV coefficient estimates of 0.88 in the no qualifications specification and of -0.27 in

\footnotetext{
${ }^{9}$ A similar approach of inverse distance weighting is adopted in a very different context by Gibbons, Machin and Silva (2009) in their analysis of housing valuations of school quality where discontinuities arise as children rarely cross administrative boundaries to attend school.
} 
the age left school specification show a strong and significant causal impact of education on crime. ${ }^{10}$

\section{Estimates by Broad Crime Type}

Table 4 shows separate estimates from models of property crime and violent crime for the discontinuity sample. There are two panels in the Table, the upper panel focussing on the population weighted models and the lower panel reporting IDW estimates. There is evidence of a strong and significant crime reducing education effect for property crime, but the violent crime specifications are much less precisely determined and the estimated effects are insignificantly different from zero. In the case of property crimes, the IV estimates suggest that a one percent point fall in the proportion with no educational qualifications reduces crime by between 0.85 and 1.00 percent. A 1 percent increase in the average age men leave school generates a 0.25 to 0.30 percent fall in their probability of being convicted for a property crime.

\section{Robustness}

In Table 5 we present a number of robustness checks of our main discontinuity sample results for property crimes. The upper panel of the Table considers robustness to functional form, for results from the standard regression models and for the inverse distance weighted specifications. Four such robustness checks are reported, revealing how the estimates change on adding birth cohort age specific trends, linear and quadratic birth cohort variables or linear splines on each side of the discontinuity. In all cases the

\footnotetext{
${ }^{10}$ The specifications in Tables 2 and 3 include full sets of age and year dummies. This choice of functional form is driven by the data matching procedure (see Data Appendix A). Adopting a different specification focussing more on birth cohort, for example as done by including a quartic in birth cohort and age (or age dummies) in the earnings-education studies of Oreopoulos (2006) or Devereux and Hart (2010), produced similar results which, if anything, were slightly larger in magnitude. For this latter choice of functional form in the IDW models, the estimated IV coefficients (standard error) were $0.777(0.316)$ and -0.249 (0.092) respectively in the no qualifications and age left school specifications. Other functional form robustness checks are reported below in Table 5.
} 
IV estimates remain statistically significant and of similar magnitude to the baseline estimates in Table 4. If anything, the magnitude of the causal estimates increase after these amendments of functional form.

In the lower panel of Table 5 we also report the results from a simple falsification exercise which sets a 'placebo' school leaving age law in September 1969. The first cohort affected would have been the 1954 one and we include all males aged 18 to 40 born between 1947 and 1957 (to exclude those affected by the actual school leaving age increase). We find all the IV estimates to be extremely small in magnitude and none are even close to being significant. These robustness checks validate the causal nature of the causal relationship observed despite the potential issues of the rising trends in crime and education over the years.

\section{Discussion and Social Benefits Calculation}

The empirical analysis identifies a robust, causal impact of education on property crime. Results on violent crime are more volatile and no clear pattern emerged, possibly because of the noisier nature of the data, or perhaps (in line with the arguments discussed in the context of existing literature in Section 2) because the crime reducing potential of education applies more to property than violent crimes. However, the vast majority of crimes that occur are property crimes (these represent more than 70 percent of offences recorded by the police and indictable offences tried in courts). Given that we have identified a sizable crime reducing impact of education, it thus seems interesting to try to say something about the economic importance of such an effect. We have therefore carried out a simple, and in our view informative, calculation of the possible social savings that could result from such reduction in property crime. 
Table 6 shows estimates of the social benefits from crime reduction that would follow from a 1 percent reduction in the percentage of individuals with no educational qualifications. Using cost of crime estimates from Dubourg et al. (2005) we calculate that the average cost of a property offence tried in court comes to $£ 1,369$ in $2007 / 8$ prices. The Table 4 IV estimates suggest that a 1 percent reduction in the population with no educational qualifications resulted in a 0.851 to 0.999 percent fall in property crime convictions. As 91,800 men aged 18 and over were convicted of property offences in 2007/8, this translates to between 791 and 917 fewer convictions. Since only 2 percent of property crimes committed in $2007 / 8$ ended up with a court conviction, this corresponds to an estimated net crime reduction of between 39,525 and 45,836 offences. ${ }^{11}$ For this scale of crime reduction, the average social benefits can be calculated as ranging between $£ 54.1$ and $£ 62.7$ million.

These are sizable social benefits, especially if one considers that the average cost to the government of a year of education for a secondary school student in 2007/8 prices was approximately $£ 4,200$ (Goodman and Sibieta, 2006). The cost of making $1 \%$ of those with no qualifications stay on and get some qualification as a result of raising the school leaving age would be a little over $£ 20$ million each year. The yearly net social benefits from crime reduction would be at first negative as only a few cohorts would be affected by the policy. However, as can be seen in the last panel of Table 6 , this would be quickly reversed and by the third or fourth year the yearly net social benefits would become

\footnotetext{
${ }^{11}$ The best estimates of criminal activity in England and Wales come from annual reported victimisation in the British Crime Survey. The 2007/08 BCS recorded just over 5.8 million property offences. If we assume that men commit a relatively similar proportion of such crimes as they are convicted for ( 78 percent), we can calculate that they are responsible for just under 4.6 million of the property offences committed that year. It is important to note the British Crime Survey criminal activity measure is also the basis for the official calculation of cost of crime by Dubourg et al. (2005) and should therefore be our reference (rather than number of offences recorded by the police) for this cost benefit calculation.
} 
positive. A decade after increasing the school leaving age, the net social benefits would become substantial and reach between $£ 21$ and $£ 30$ million. ${ }^{12}$

This cost-benefit calculation should be carefully and cautiously interpreted. For one thing, it presumes that the $1 \%$ who could benefit from staying on and getting some qualifications can be well targeted. In reality it may prove difficult to identify the right population and we cannot measure the exact cost of obtaining an educational qualification. Secondly, general equilibrium effects are not factored in. However these seem unlikely to significantly offset the large net social benefit estimates the calculation implies. ${ }^{13}$ The social savings appear to be quite large over time, confirming that crime reduction is an extra indirect benefit that can be generated from education policies (as highlighted by Lochner's 2010 review).

\section{$\underline{\text { 4. Conclusions }}$}

This paper presents new evidence on the crime reducing effect of education, using a regression discontinuity approach to identify a causal connection. Other than Lochner and Moretti (2004) for the US and the results reported in this paper, evidence on this is not available. We report empirical findings showing that education reduces property crime and that improved education can therefore generate social benefits. The estimated

\footnotetext{
${ }^{12}$ Our net social benefit estimate is much smaller than the $\$ 1.4$ billion put forward by Lochner and Moretti (2004). The main reason is that we do not identify a clear impact of education on violent crime and especially murder which account for 80 percent of their crime savings. When only considering prevented property crimes, then their estimate is just above $\$ 52$ million or $£ 35$ million (at the average $1.5 £ / \$$ exchange rate from 2002) which falls very close to our lower bound estimate of the social savings of crime. Still, since the population of England and Wales is more than five times smaller than that of the US, this represents a very substantial social benefit per capita.

${ }^{13}$ One way of thinking about general equilibrium effects would be to consider that the increase in the proportion of individuals with some qualification could reduce the wages of workers already with this education level. Considering the wage effects on crime with an elasticity of -1 as reported in Machin and Meghir (2004), it could be possible that it would increase the crime participation of the latter group. However we believe that this should be more than compensated by the decrease in crimes from the wage premium (estimated at around $40 \%$ ) experienced by the individuals now obtaining some qualification.
} 
social savings from crime reduction implied by our estimates are substantial and, fairly quickly after the school reform, imply sizable net social benefits from the additional schooling.

The existence of a causal crime reducing effect of education has potentially important implications for longer term efforts aimed at reducing crime. For example, policies that subsidise schooling and human capital investment have significant potential to reduce crime in the longer run by increasing skill levels. At the very least, our results confirm that improving education amongst offenders and potential offenders should be viewed as a key policy lever that can be used in the drive to combat crime. 


\section{$\underline{\text { References }}$}

Anderson, D. M. (2009) In School and Out of Trouble? The Minimum Dropout Age and Juvenile Crime, University of Washington mimeo.

Card, D. (1999) (1999) The Causal Effect of Education on Earnings, in Ashenfelter, O. and D. Card (eds.) (1999) Handbook of Labor Economics, North Holland.

Chevalier, A. (2004) Parental Education and Child's Education: A Natural Experiment, Working Paper.

Chevalier, A., C. Harmon, V. O'Sullivan, and I. Walker (2005) The Impact of Parental Income and Education on the Schooling of Their Children, Institute for Fiscal Studies Working Paper 05/05.

Devereux, P. and R. Hart (2010) Forced to be Rich? Returns to Compulsory Schooling in Britain, Economic Journal, forthcoming.

Draca, M., S. Machin and R. Witt (2010) Panic on the Streets of London: Crime, Police and the July 2005 Terror Attacks, American Economic Review, forthcoming.

Dubourg, R., J. Hamed, and J. Thorns (2005) The Economic and Social Costs of Crime against Individuals and Households 2003/04, Home Office Online Report 30/05.

Doyle, O., C. Harmon, and I. Walker (2007) The Impact of Parental Income and Education on Child Health: Further Evidence for England, UCD Geary Institute Working Paper Number 6/2007.

Farrington, D. (1986) Age and Crime, Chicago: University of Chicago Press.

Farrington, D. (2001) Predicting Persistent Young Offenders, in MacDowell, G. and J. Smith (eds.) Juvenile Delinquency in the United States and the United Kingdom, London: Macmillan Press.

Galindo-Rueda, F. (2003) The Intergenerational Effect of Parental Schooling: Evidence from the British 1947 School Leaving Age Reform, Working Paper.

Gibbons, S., S. Machin and O. Silva (2009) Valuing School Quality Using Boundary Discontinuities, Centre for Economic Performance, LSE, mimeo.

Goodman, A. and L. Sibieta (2006) Public Spending on Education in the UK, Institute for Fiscal Studies Briefing Note No. 71.

Grogger, J. (1998) Market Wages and Youth Crime, Journal of Labour Economics, 16, 756-791. 
Harmon, C. and I. Walker (1995) Estimates of the Economic Return to Schooling for the United Kingdom, American Economic Review, 85, 1278-1286.

Hjalmarsson, R. (2008) Criminal Justice Involvement and High School Completion, Journal of Urban Economics, 63, 613-630

Jacob, B. and L. Lefgren (2003) Are Idle Hands the Devil's Workshop? Incapacitation, Concentration and Juvenile Crime, American Economic Review, 93, 1560-1577.

Levitt, S. and L. Lochner (2001) The Determinants of Juvenile Crime," in Gruber, J. (ed.) Risky Behavior Among Youths: An Economic Analysis, Chicago: University of Chicago Press.

Lindeboom, M., A. Llena-Nozal, and B. van der Klauw (2009) Parental Education and Child Health: Evidence from a Schooling Reform, Journal of Health Economics, $28,109-131$

Lochner, L. (2004) Education, Work and Crime: A Human Capital Approach.” International Economic Review, 45, 811-843.

Lochner, L. (2010) Non-Production Benefits of Education, forthcoming Chapter in Hanushek, E., S. Machin and L. Woessmann (eds.) Handbook of the Economics of Education, North Holland: Amsterdam.

Lochner, L. and E. Moretti (2004) The Effect of Education on Crime: Evidence From Prison Inmates, Arrests and Self-Reports, American Economic Review, 94, 155189.

Luallen, J. (2006) School's Out......Forever: A Study of Juvenile Crime, At-Risk Youths and Teacher Strikes, Journal of Urban Economics, 59, 75-103.

Machin, S. and O. Marie (2010) Crime and Police Resources: The Street Crime Initiative, Journal of the European Economic Association, forthcoming.

Machin, S. and C. Meghir (2004) Crime and Economic Incentives, Journal of Human Resources, 39, 958-979.

Machin, S., O. Marie and S. Vujić (2010) The Crime Reducing Effect of Education, IZA Discussion Paper 5000.

Oreopoulos, P. (2006) Estimating Average and Local Average Treatment Effects of Education When Compulsory Schooling Laws Really Matter, American Economic Review, 96, 152-175. 
Oreopoulos, P. (2007) Do Dropouts Drop out too Soon? Wealth, Health and Happiness From Compulsory Schooling, Journal of Public Economics, 91, 2213-2229.

Sabates, R. (2008) Educational Attainment and Juvenile Crime. Area-Level Analysis Using Three Cohorts of Young People, British Journal of Criminology, 48, 395409.

Sabates, R. (2009) Educational Expansion, Economic Growth and Antisocial Behaviour: Evidence from England, Educational Studies, iFirst, 1-9.

Sabates, R. and L. Feinstein (2008) Effects of Government Initiatives on Youth Crime, Oxford Economic Papers 60, 462-83.

Tauchen, H., A. Witte, and H. Griesinger (1994) Criminal Deterrence: Revisiting the Issue With a Birth Cohort, Review of Economics and Statistics, 76, 399-412. 
Figure 1:

Education Discontinuities Around the Compulsory School Leaving Age Increase

a) No Educational Qualifications

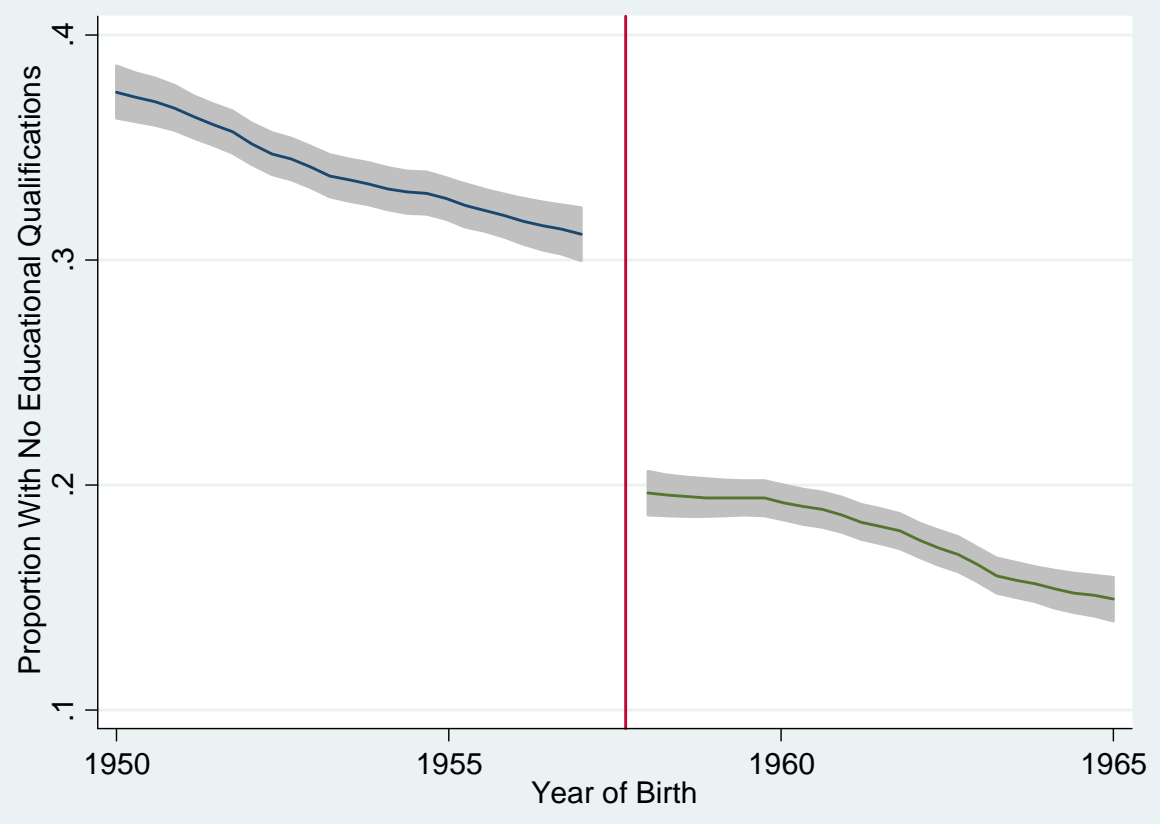

b) Age Left School

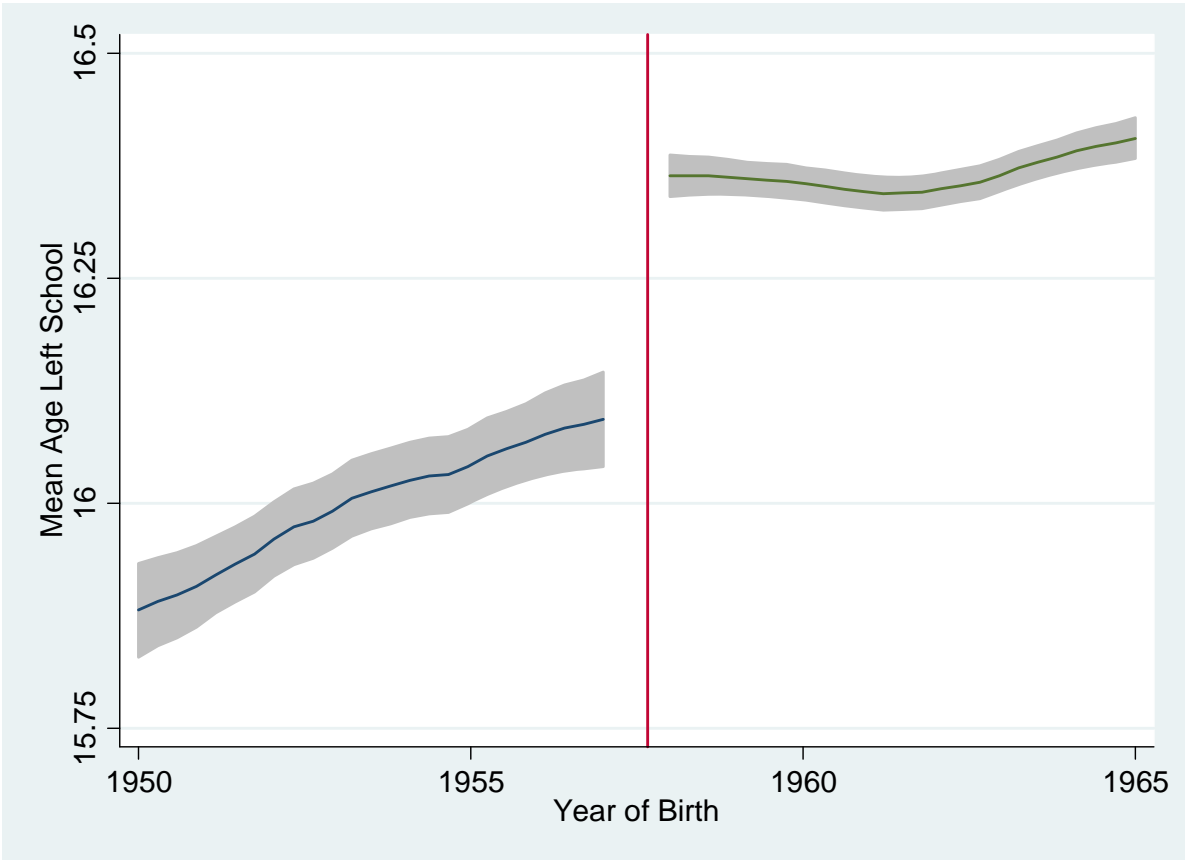

Notes: Based on General Household Survey Data From 1972 to 1996, Men Aged 18 to 40. Lines denote kernel weighted smooth polynomial fit to data points before and after the discontinuity denoted by the vertical line. Grey shaded area is $95 \%$ confidence interval. 
Figure 2:

\section{Crime Discontinuities Around the Compulsory School Leaving Age Increase}

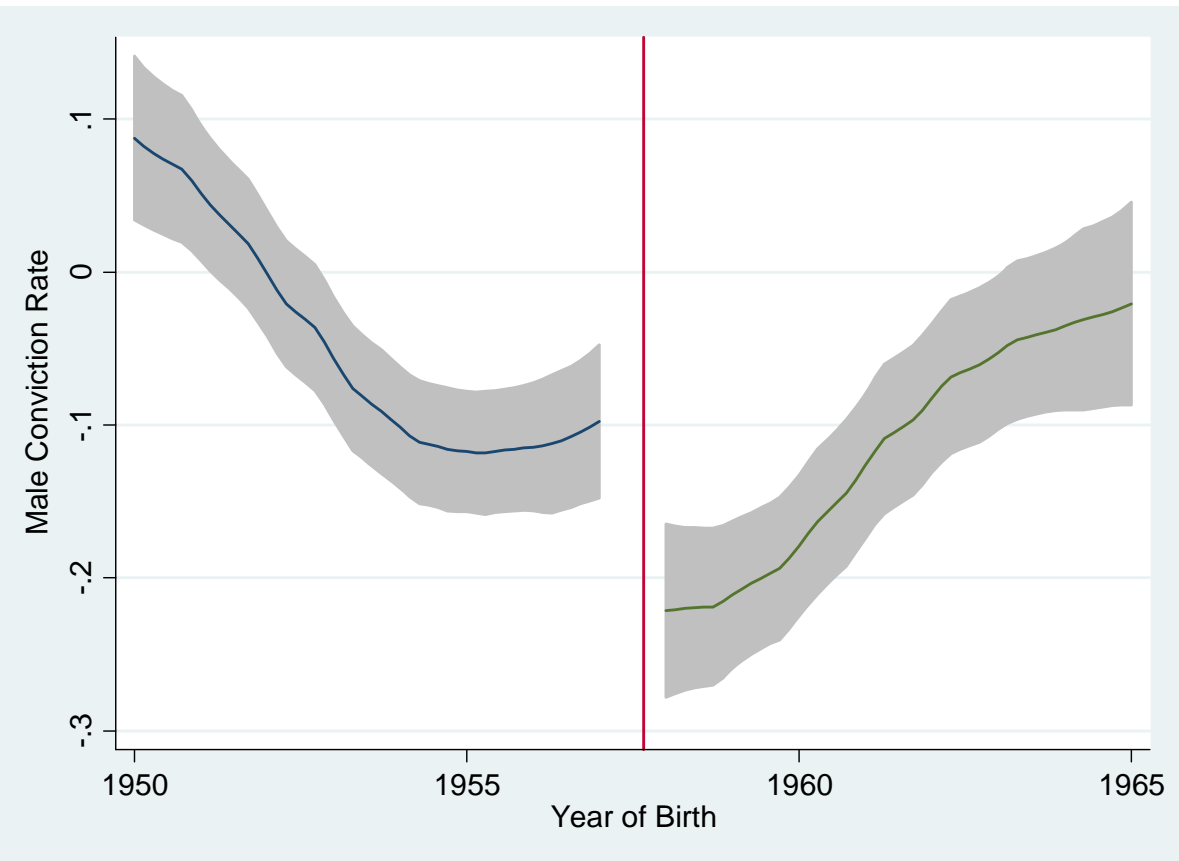

Notes: Based on Offenders Index Data From 1972 to 1996, Men Aged 18 to 40. Lines denote kernel weighted smooth polynomial fit to data points before and after the discontinuity denoted by the vertical line. Grey shaded area is $95 \%$ confidence interval. 
Table 1: Example Estimates of Crime-Education Associations

\begin{tabular}{|c|c|c|c|c|c|}
\hline Data & Description & Crime & Education & $\begin{array}{l}\text { Men, } \\
\text { Aged } \\
18-40 \\
\end{array}$ & $\begin{array}{c}\text { Women, } \\
\text { Aged } \\
18-40 \\
\end{array}$ \\
\hline $\begin{array}{l}\text { Offenders Index } \\
\text { Database, England } \\
\text { and Wales }\end{array}$ & $\begin{array}{c}\text { Matched OID } \\
\text { convictions to GHS } \\
\text { education data by } \\
\text { age and year, 1972- } \\
1996^{\mathrm{a}}\end{array}$ & $\begin{array}{c}\text { Log } \\
\text { (Convictions } \\
\text { per } \\
1000 \\
\text { Population) }\end{array}$ & $\begin{array}{c}\text { No } \\
\text { Qualifications }\end{array}$ & $\begin{array}{c}0.40 \\
(0.09)\end{array}$ & $\begin{array}{l}-0.04 \\
(0.18)\end{array}$ \\
\hline Census & $\begin{array}{l}3 \% \text { Individual } \\
\text { Sample, } 2001^{\mathrm{b}}\end{array}$ & $\begin{array}{c}\text { Imprisonment } \\
\text { Rate }\end{array}$ & $\begin{array}{c}\text { No } \\
\text { Qualifications }\end{array}$ & $\begin{array}{c}1.61 \\
(0.06) \\
{[0.60]}\end{array}$ & $\begin{array}{l}1.72 \\
(0.30) \\
{[0.04]}\end{array}$ \\
\hline \multirow[t]{2}{*}{$\begin{array}{l}\text { British Crime } \\
\text { Survey }\end{array}$} & \multirow[t]{2}{*}{$\begin{array}{l}\text { Self report data, } \\
2001 / 2-2007 / 8^{c}\end{array}$} & $\begin{array}{c}\text { Ever Been } \\
\text { Arrested }\end{array}$ & $\begin{array}{c}\text { No } \\
\text { Qualifications }\end{array}$ & $\begin{array}{c}0.84 \\
(0.08) \\
{[15.90]}\end{array}$ & $\begin{array}{c}1.13 \\
(0.10) \\
{[7.30]}\end{array}$ \\
\hline & & $\begin{array}{l}\text { Ever Been in } \\
\text { Court as the } \\
\text { Accused }\end{array}$ & $\begin{array}{c}\text { No } \\
\text { Qualifications }\end{array}$ & $\begin{array}{c}0.90 \\
(0.07) \\
{[12.70]}\end{array}$ & $\begin{array}{c}1.01 \\
(0.10) \\
{[3.90]}\end{array}$ \\
\hline
\end{tabular}

Notes: a - Population weighted regression least squares regression coefficients reported (standard errors in round parentheses). Sample size is 410 age-year cells for Men Aged 18-40 and Women Aged 18-40. Includes GHS control variables (proportion British born, proportion employed, proportion non-white, proportion living in London); $b-$ Logit coefficients reported (standard errors in round parentheses, marginal effects X 100 in square parentheses). Sample size is 278831 Men and 212197 Women. Specifications include a full set of age dummies, 15 country of birth dummies, non-white dummy, 5 marital status dummies, dummy for never worked, dummies for country of residence; c - Logit coefficients reported (standard errors in round parentheses, marginal effects X 100 in square parentheses). Based on the pooled 2001/2-2007/8 British Crime Surveys. Sample size for Ever Been Arrested is 6526 Men and 8073 Women. Sample size for Ever Been in Court as the Accused is 9837 Men and 12252 Women. The precise questions asked are: 'Have you ever been arrested by the police for any reason?' and 'Have you ever been in court as the person ACCUSED of committing a crime?'. Specifications include a full set of age and year dummies. See Machin, Marie and Vujić (2010) for more details. 


\section{Table 2: The Causal Effect of Education on Crime}

Log(OID Convictions Per 1000 Population), Matched to GHS by Age and Year, 1972 to 1996

\begin{tabular}{|c|c|c|c|c|c|c|c|c|c|c|}
\hline & \multicolumn{5}{|c|}{ Men, Aged 18-40, Born 1946-70 } & \multicolumn{5}{|c|}{ Men, Aged 18-40, Discontinuity Sample } \\
\hline & & \multicolumn{2}{|c|}{ No Qualifications } & \multicolumn{2}{|c|}{ Age Left School } & \multicolumn{3}{|c|}{ No Qualifications } & \multicolumn{2}{|c|}{ Age Left School } \\
\hline & $\begin{array}{c}(1) \\
\text { Crime } \\
\text { Reduced } \\
\text { Form } \\
\end{array}$ & $\begin{array}{c}(2) \\
\text { Education } \\
\text { Reduced } \\
\text { Form } \\
\end{array}$ & $\begin{array}{c}(3) \\
\text { Crime } \\
\text { Structural } \\
\text { Form }\end{array}$ & $\begin{array}{c}\text { (4) } \\
\text { Education } \\
\text { Reduced } \\
\text { Form } \\
\end{array}$ & $\begin{array}{c}(5) \\
\text { Crime } \\
\text { Structural } \\
\text { Form } \\
\end{array}$ & $\begin{array}{c}(6) \\
\text { Crime } \\
\text { Reduced } \\
\text { Form }\end{array}$ & $\begin{array}{c}\text { (7) } \\
\text { Education } \\
\text { Reduced } \\
\text { Form } \\
\end{array}$ & $\begin{array}{c}(8) \\
\text { Crime } \\
\text { Structural } \\
\text { Form } \\
\end{array}$ & $\begin{array}{c}\text { (9) } \\
\text { Education } \\
\text { Reduced } \\
\text { Form } \\
\end{array}$ & $\begin{array}{c}(10) \\
\text { Crime } \\
\text { Structural } \\
\text { Form } \\
\end{array}$ \\
\hline School Leaving Age Increase & $\begin{array}{c}-0.047 \\
(0.017)\end{array}$ & $\begin{array}{c}-0.057 \\
(0.008)\end{array}$ & & $\begin{array}{c}0.221 \\
(0.026)\end{array}$ & & $\begin{array}{c}-0.080 \\
(0.034)\end{array}$ & $\begin{array}{c}-0.113 \\
(0.019)\end{array}$ & & $\begin{array}{c}0.375 \\
(0.055)\end{array}$ & \\
\hline No Qualifications & & & $\begin{array}{c}0.817 \\
(0.308)\end{array}$ & & & & & $\begin{array}{c}0.707 \\
(0.310)\end{array}$ & & \\
\hline Age Left School & & & & & $\begin{array}{c}-0.212 \\
(0.073)\end{array}$ & & & & & $\begin{array}{c}-0.297 \\
(0.126)\end{array}$ \\
\hline F-test & $\begin{array}{c}\mathrm{F}(1,358) \\
=7.41 \\
{[\mathrm{P}=.007]}\end{array}$ & $\begin{array}{c}\mathrm{F}(1,358) \\
=46.94 \\
{[\mathrm{P}=.000]}\end{array}$ & & $\begin{array}{c}\mathrm{F}(1,358) \\
=69.86 \\
{[\mathrm{P}=.000]}\end{array}$ & & $\begin{array}{c}\mathrm{F}(1,117) \\
=5.65 \\
{[\mathrm{P}=.019]}\end{array}$ & $\begin{array}{c}\mathrm{F}(1,117) \\
=36.34 \\
{[\mathrm{P}=.000]}\end{array}$ & & $\begin{array}{c}\mathrm{F}(1,117) \\
=46.13 \\
{[\mathrm{P}=.000]}\end{array}$ & \\
\hline Age and Year Dummies & Yes & Yes & Yes & Yes & Yes & Yes & Yes & Yes & Yes & Yes \\
\hline GHS Control Variables & Yes & Yes & Yes & Yes & Yes & Yes & Yes & Yes & Yes & Yes \\
\hline Sample Size & 410 & 410 & 410 & 410 & 410 & 169 & 169 & 169 & 169 & 169 \\
\hline
\end{tabular}

Notes: Population weighted models estimated on age-year cells, including a full set of age and year dummy variables, between 1972 and 1996 . Robust standard errors in parentheses. GHS control variables included are: proportion British born, proportion employed, proportion non-white, and proportion living in London. The discontinuity sample comprises +/- four birth years around the 1957/8 cohorts which were affected by the school leaving age increase 15 years later (i.e. born between 1954-1957 and 1958-1961). 
Table 3: The Causal Effect of Education on Crime - Inverse Distance Weights

Log(OID Convictions Per 1000 Population), Matched to GHS by Age and Year, 1972 to 1996

\begin{tabular}{|c|c|c|c|c|c|c|c|c|c|c|}
\hline & \multicolumn{5}{|c|}{ Men, Aged 18-40, Born 1946-70 } & \multicolumn{5}{|c|}{ Men, Aged 18-40, Discontinuity Sample } \\
\hline & & \multicolumn{2}{|c|}{ No Qualifications } & \multicolumn{2}{|c|}{ Age Left School } & \multicolumn{3}{|c|}{ No Qualifications } & \multicolumn{2}{|c|}{ Age Left School } \\
\hline & $\begin{array}{c}(1) \\
\text { Crime } \\
\text { Reduced } \\
\text { Form }\end{array}$ & $\begin{array}{c}(2) \\
\text { Education } \\
\text { Reduced } \\
\text { Form } \\
\end{array}$ & $\begin{array}{c}(3) \\
\text { Crime } \\
\text { Structural } \\
\text { Form } \\
\end{array}$ & $\begin{array}{c}(4) \\
\text { Education } \\
\text { Reduced } \\
\text { Form } \\
\end{array}$ & $\begin{array}{c}(5) \\
\text { Crime } \\
\text { Structural } \\
\text { Form } \\
\end{array}$ & $\begin{array}{c}(6) \\
\text { Crime } \\
\text { Reduced } \\
\text { Form } \\
\end{array}$ & $\begin{array}{c}(7) \\
\text { Education } \\
\text { Reduced } \\
\text { Form } \\
\end{array}$ & $\begin{array}{c}(8) \\
\text { Crime } \\
\text { Structural } \\
\text { Form } \\
\end{array}$ & $\begin{array}{c}\text { (9) } \\
\text { Education } \\
\text { Reduced } \\
\text { Form } \\
\end{array}$ & $\begin{array}{c}(10) \\
\text { Crime } \\
\text { Structural } \\
\text { Form } \\
\end{array}$ \\
\hline School Leaving Age Increase & $\begin{array}{c}-0.053 \\
(0.016)\end{array}$ & $\begin{array}{c}-0.081 \\
(0.008)\end{array}$ & & $\begin{array}{c}0.282 \\
(0.028)\end{array}$ & & $\begin{array}{c}-0.119 \\
(0.032)\end{array}$ & $\begin{array}{c}-0.135 \\
(0.021)\end{array}$ & & $\begin{array}{c}0.445 \\
(0.058)\end{array}$ & \\
\hline No Qualifications & & & $\begin{array}{c}0.658 \\
(0.201)\end{array}$ & & & & & $\begin{array}{c}0.882 \\
(0.310)\end{array}$ & & \\
\hline Age Left School & & & & & $\begin{array}{l}-0.189 \\
(0.055)\end{array}$ & & & & & $\begin{array}{c}-0.267 \\
(0.077)\end{array}$ \\
\hline F-test & $\begin{array}{c}\mathrm{F}(1,358) \\
=11.56 \\
{[\mathrm{P}=.001]}\end{array}$ & $\begin{array}{c}\mathrm{F}(1,358) \\
=67.42 \\
{[\mathrm{P}=.000]}\end{array}$ & & $\begin{array}{c}\mathrm{F}(1,358) \\
=98.83 \\
{[\mathrm{P}=.000]}\end{array}$ & & $\begin{array}{c}\mathrm{F}(1,117) \\
=13.26 \\
{[\mathrm{P}=.000]}\end{array}$ & $\begin{array}{c}\mathrm{F}(1,117) \\
=42.14 \\
{[\mathrm{P}=.000]}\end{array}$ & & $\begin{array}{c}\mathrm{F}(1,117) \\
=58.89 \\
{[\mathrm{P}=.000]}\end{array}$ & \\
\hline Age and Year Dummies & Yes & Yes & Yes & Yes & Yes & Yes & Yes & Yes & Yes & Yes \\
\hline GHS Control Variables & Yes & Yes & Yes & Yes & Yes & Yes & Yes & Yes & Yes & Yes \\
\hline Sample Size & 410 & 410 & 410 & 410 & 410 & 169 & 169 & 169 & 169 & 169 \\
\hline
\end{tabular}

Notes: As for Table 2. 
Table 4: The Causal Effect of Education on Crime, by Broad Types of Crime

Men, Aged 18-40, Born 1946-70, Discontinuity Sample

Log(Property Convictions per 1000 Population)

\begin{tabular}{|c|c|c|c|c|c|c|c|c|c|c|}
\hline \multirow[t]{2}{*}{ A. Population Weighted } & \multicolumn{3}{|c|}{ No Qualifications } & \multicolumn{2}{|c|}{ Age Left School } & \multicolumn{3}{|c|}{ No Qualifications } & \multicolumn{2}{|c|}{ Age Left School } \\
\hline & $\begin{array}{c}(1) \\
\text { Crime } \\
\text { Reduced } \\
\text { Form }\end{array}$ & $\begin{array}{c}(2) \\
\text { Education } \\
\text { Reduced } \\
\text { Form }\end{array}$ & $\begin{array}{c}(3) \\
\text { Crime } \\
\text { Structural } \\
\text { Form }\end{array}$ & $\begin{array}{c}(4) \\
\text { Education } \\
\text { Reduced } \\
\text { Form }\end{array}$ & $\begin{array}{c}(5) \\
\text { Crime } \\
\text { Structural } \\
\text { Form }\end{array}$ & $\begin{array}{c}(6) \\
\text { Crime } \\
\text { Reduced } \\
\text { Form }\end{array}$ & $\begin{array}{c}(7) \\
\text { Education } \\
\text { Reduced } \\
\text { Form }\end{array}$ & $\begin{array}{c}(8) \\
\text { Crime } \\
\text { Structural } \\
\text { Form }\end{array}$ & $\begin{array}{c}(9) \\
\text { Education } \\
\text { Reduced } \\
\text { Form }\end{array}$ & $\begin{array}{c}(10) \\
\text { Crime } \\
\text { Structural } \\
\text { Form }\end{array}$ \\
\hline School Leaving Age Increase & $\begin{array}{c}-0.096 \\
(0.039)\end{array}$ & $\begin{array}{c}-0.113 \\
(0.019)\end{array}$ & & $\begin{array}{c}0.375 \\
(0.055)\end{array}$ & & $\begin{array}{c}-0.028 \\
(0.057)\end{array}$ & $\begin{array}{l}-0.113 \\
(0.019)\end{array}$ & & $\begin{array}{c}0.375 \\
(0.055)\end{array}$ & \\
\hline No Qualifications & & & $\begin{array}{c}0.851 \\
(0.370)\end{array}$ & & & & & $\begin{array}{c}0.251 \\
(0.490)\end{array}$ & & \\
\hline Age Left School & & & & & $\begin{array}{l}-0.257 \\
(0.108)\end{array}$ & & & & & $\begin{array}{l}-0.076 \\
(0.152)\end{array}$ \\
\hline F-test & $\begin{array}{c}\mathrm{F}(1,117) \\
=6.02 \\
{[\mathrm{P}=.016]}\end{array}$ & $\begin{array}{c}\mathrm{F}(1,117) \\
=36.34 \\
{[\mathrm{P}=.000]}\end{array}$ & & $\begin{array}{c}\mathrm{F}(1,117) \\
=46.13 \\
{[\mathrm{P}=.000]}\end{array}$ & & $\begin{array}{c}\mathrm{F}(1,117) \\
\quad=0.25 \\
{[\mathrm{P}=.619]}\end{array}$ & $\begin{array}{c}\mathrm{F}(1,117) \\
=36.34 \\
{[\mathrm{P}=.000]}\end{array}$ & & $\begin{array}{c}\mathrm{F}(1,117) \\
=46.13 \\
{[\mathrm{P}=.000]}\end{array}$ & \\
\hline B. Inverse Distance Weighted & & No Qua & ications & Age Le & School & & No Qua & fications & Age Lef & School \\
\hline & $\begin{array}{c}(1) \\
\text { Crime } \\
\text { Reduced } \\
\text { Form }\end{array}$ & $\begin{array}{c}(2) \\
\text { Education } \\
\text { Reduced } \\
\text { Form } \\
\end{array}$ & $\begin{array}{c}(3) \\
\text { Crime } \\
\text { Structural } \\
\text { Form } \\
\end{array}$ & $\begin{array}{c}(4) \\
\text { Education } \\
\text { Reduced } \\
\text { Form } \\
\end{array}$ & $\begin{array}{c}(5) \\
\text { Crime } \\
\text { Structural } \\
\text { Form }\end{array}$ & $\begin{array}{c}(6) \\
\text { Crime } \\
\text { Reduced } \\
\text { Form }\end{array}$ & $\begin{array}{c}(7) \\
\text { Education } \\
\text { Reduced } \\
\text { Form }\end{array}$ & $\begin{array}{c}(8) \\
\text { Crime } \\
\text { Structural } \\
\text { Form }\end{array}$ & $\begin{array}{c}\text { (4) } \\
\text { Education } \\
\text { Reduced } \\
\text { Form }\end{array}$ & $\begin{array}{c}(10) \\
\text { Crime } \\
\text { Structural } \\
\text { Form }\end{array}$ \\
\hline School Leaving Age Increase & $\begin{array}{c}-0.135 \\
(0.037)\end{array}$ & $\begin{array}{c}-0.135 \\
(0.021)\end{array}$ & & $\begin{array}{c}0.445 \\
(0.058)\end{array}$ & & $\begin{array}{c}-0.067 \\
(0.059)\end{array}$ & $\begin{array}{c}-0.135 \\
(0.021)\end{array}$ & & $\begin{array}{c}0.445 \\
(0.058)\end{array}$ & \\
\hline No Qualifications & & & $\begin{array}{c}0.999 \\
(0.306)\end{array}$ & & & & & $\begin{array}{c}0.498 \\
(0.426)\end{array}$ & & \\
\hline Age Left School & & & & & $\begin{array}{c}-0.303 \\
(0.089)\end{array}$ & & & & & $\begin{array}{c}-0.151 \\
(0.131)\end{array}$ \\
\hline F-test & $\begin{array}{c}\mathrm{F}(1,117) \\
=13.58 \\
{[\mathrm{P}=.000]}\end{array}$ & $\begin{array}{c}\mathrm{F}(1,117) \\
=42.14 \\
{[\mathrm{P}=.000]}\end{array}$ & & $\begin{array}{c}\mathrm{F}(1,117) \\
=58.89 \\
{[\mathrm{P}=.000]}\end{array}$ & & $\begin{array}{c}\mathrm{F}(1,117) \\
=1.33 \\
{[\mathrm{P}=.252]}\end{array}$ & $\begin{array}{c}\mathrm{F}(1,117) \\
=42.14 \\
{[\mathrm{P}=.000]}\end{array}$ & & $\begin{array}{c}\mathrm{F}(1,117) \\
=58.89 \\
{[\mathrm{P}=.000]}\end{array}$ & \\
\hline
\end{tabular}

Notes: As for Table 2. Sample size is 169 in all cases.

Log(Violent Convictions per 1000 Population)

$-0.076$

$=46.13$

ctural 
Table 5: Robustness to Functional Form and a Falsification Exercise

\begin{tabular}{lcccc}
\hline & \multicolumn{2}{c}{$\begin{array}{c}\text { Log(OID Property Convictions Per 1000 Population), } \\
\text { Matched to GHS by Age and Year, 1972 to 1996 }\end{array}$} \\
\hline & $\begin{array}{c}\text { Men, Aged 18-40, } \\
\text { Discontinuity Sample, } \\
\text { Population Weighted }\end{array}$ & $\begin{array}{c}\text { Men, Aged 18-40, } \\
\text { Discontinuity Sample, } \\
\text { Inverse Distance Weighted }\end{array}$ \\
\hline A. Functional Form & No & Age Left & No & Age Left School \\
& Qualifications & School & Qualifications & \\
\hline Baseline Estimates From Table 4 & 0.851 & -0.257 & 0.999 & -0.303 \\
Birth Cohort Specific Age Trends & $(0.370)$ & $(0.108)$ & $(0.306)$ & $(0.087)$ \\
Linear in Birth Cohort & 0.726 & -0.212 & 1.061 & -0.288 \\
Quadratic in Birth Cohort & $(0.421)$ & $(0.120)$ & $(0.408)$ & $(0.103)$ \\
& 1.051 & -0.304 & 1.200 & -0.350 \\
Linear Splines & $(0.511)$ & $(0.143)$ & $(0.423)$ & $(0.115)$ \\
\hline B. Placebo SLA Increase & 1.136 & -0.315 & 1.254 & -0.352 \\
\hline Affected Cohort 1954, Men aged 18-40, & $(0.529)$ & $(0.140)$ & $(0.445)$ & $(0.114)$ \\
Born 1947 to 1957 & 1.034 & -0.302 & 1.185 & -0.350 \\
& $(0.507)$ & $(0.145)$ & $(0.419)$ & $(0.116)$ \\
\hline
\end{tabular}

Notes: As for Table 4. The placebo increase in Panel B refers to an 'imaginary' law raising the school leaving age from 15 to 16 that took force in September 1969, three years before the actual increase. 


\section{Table 6: Social Benefits from Decreasing Population with No Educational Qualification by 1 Percent}

\begin{tabular}{|c|c|c|c|}
\hline \multicolumn{2}{|c|}{$\begin{array}{l}\text { Causal Estimate of SLA Change of } 1 \% \text { Change of } \\
\text { Population with No Qualification }\end{array}$} & Estimate $=0.851$ & Estimate $=0.999$ \\
\hline \multicolumn{2}{|c|}{ Cost in Anticipation of Crime } & 174 & 174 \\
\hline \multicolumn{2}{|c|}{ Cost as Consequence of Crime } & 787 & 787 \\
\hline \multicolumn{2}{|c|}{ Cost to the Criminal Justice System } & 407 & 407 \\
\hline \multicolumn{2}{|c|}{ Total Cost per Crime } & 1.369 & 1.369 \\
\hline \multicolumn{2}{|l|}{ Number of Male Convictions } & 91.800 & 91.801 \\
\hline \multicolumn{2}{|c|}{ Estimated Change in Male Convictions } & 790 & 917 \\
\hline \multicolumn{2}{|c|}{ Estimated Change in Male Crimes } & 4.587 .960 & 4.587 .960 \\
\hline \multicolumn{2}{|c|}{ Average Social Benefit from Crime Reduction } & 54.103.619 & 62.741 .986 \\
\hline \multicolumn{2}{|c|}{ Cost per Student of One Year of Secondary School } & 4.244 & 4.244 \\
\hline \multicolumn{2}{|c|}{ Number of Pupils in Education Aged 16} & 493,000 & 493,000 \\
\hline \multicolumn{2}{|c|}{ Cost of 1\% Increase or Extra Year of Education } & $20,922,920$ & $20,922,920$ \\
\hline \multirow{4}{*}{$\begin{array}{l}\text { Yearly Net Social Benefit } \\
\text { from Crime Reduction }\end{array}$} & 1 Year after SLA & $-13,822,842$ & $-12,689,220$ \\
\hline & 3 Years after SLA & $-2,257,534$ & 722,645 \\
\hline & 5 Years after SLA & $6,705,272$ & $11,116,482$ \\
\hline & 10 Years after SLA & $23,260,601$ & $30,315,091$ \\
\hline
\end{tabular}

Notes: All costs are inflated to represent 2007/08 real prices using changes in the Consumer Price Index. The cost of crime estimates are taken from Dubourg et al. (2005). These estimates can be split between three main channels that are presented in the rows above the total cost per crime. They are based on British Crime Survey victimisation measures of criminal activity and are all weighted for the probability of an offence leading to police involvement, a conviction, and possible incarceration. The estimated change in male crimes is adjusted by the number of crimes per conviction (i.e. $1 / 0.020=50$ ). The cost of one year of secondary school per student is from Goodman and Sibieta (2006). There were almost half a million pupils aged 16 in school in 2007/08. We consider the impact of education on a 1 percent increase in this stock of pupils to calculate the yearly net social benefit as the number of individuals treated with the extra year of schooling increases over time. We do this after $1,3,5$, and 10 years weighting by the proportion of property crimes by age for each cohorts affected by the SLA. 


\section{Appendix A}

\section{Data Description}

\section{Offenders Index Database (OID)}

Our analysis uses OID data from 1972 to 1996, which we match to General Household Survey data by age cohort and survey year. The version of the Offenders Index Database to which we have access holds criminal history data for offenders convicted of standard list offences between 1963 and 2003. Standard list offences are all indictable or triable either way offences, plus a few of the more serious summary offences. Standard list class codes are set out in the Offenders Index codebook. The data are derived from the Court Appearances system and are updated quarterly.

The data set holds anonymous samples (of about 4 weeks) for each year from the early 1960s onwards. The selection of offenders is done by analysis of the court appearance data using the date to select relevant offenders. Selection is based on the following criteria: select offenders where they appeared in court during the first week in March, the second week in June, the third week in September and the third week in November. ${ }^{14}$

The following variables are recorded for each offender: Offenders Index (OI) Number, Date of Birth, Gender, Ethnicity, Appearance Date, Court Code, Curfew Orders, Date of Previous Court Appearance, Age at Appearance, Number of Previous Appearances, Number of Subsequent Appearances, Police Force Code, Offence Class Code, Offence Sub Class, Proceedings Type, Plea, Disposal 1-4 Code, Disposal 1-4 Amount, Disposal 14 Units, Count of Previous Offences, Count of Subsequent Offences.

Matching OID to ONS population data, we calculated offending rates (per 1000 population) by age cohort and year, separately for men and women, using Date of Birth and Gender variables. Criminal offences have been broadly categorised as property crimes (burglary and theft and handling stolen goods) and violent crimes (violence

\footnotetext{
${ }^{14}$ The first week in any calendar month is the week where the Monday is the first Monday in that month.
} 
against the person and robbery), using categorisation in the Offence Class Code variable. ${ }^{15}$ The overall conviction rate we use is the sum of the two.

The data structure for men and women, with means of the total conviction rate per 1000 population, as well as property and violent conviction rates, is as follows:

\begin{tabular}{cccccccc}
\hline $\begin{array}{l}\text { OID } \\
\text { Year }\end{array}$ & $\begin{array}{l}\text { Age } \\
\text { Range }\end{array}$ & $\begin{array}{c}\text { Men, } \\
\text { Conviction }\end{array}$ & $\begin{array}{c}\text { Men, } \\
\text { Property }\end{array}$ & $\begin{array}{c}\text { Men, } \\
\text { Violent }\end{array}$ & $\begin{array}{c}\text { Women, } \\
\text { Conviction }\end{array}$ & $\begin{array}{c}\text { Women, } \\
\text { Property }\end{array}$ & $\begin{array}{c}\text { Women, } \\
\text { Violent }\end{array}$ \\
\hline 1972 & $18-25$ & 2.71 & 2.26 & 0.45 & 0.36 & 0.34 & 0.02 \\
1973 & $18-26$ & 2.31 & 1.85 & 0.46 & 0.34 & 0.31 & 0.02 \\
1974 & $18-27$ & 2.57 & 2.13 & 0.44 & 0.39 & 0.37 & 0.02 \\
1975 & $18-28$ & 2.90 & 2.34 & 0.56 & 0.43 & 0.40 & 0.03 \\
1976 & $18-29$ & 2.72 & 2.13 & 0.59 & 0.45 & 0.41 & 0.04 \\
1977 & $18-30$ & 2.62 & 2.13 & 0.49 & 0.44 & 0.41 & 0.04 \\
1978 & $18-31$ & 2.44 & 1.96 & 0.47 & 0.46 & 043 & 0.03 \\
1979 & $18-32$ & 2.39 & 1.83 & 0.56 & 0.42 & 0.38 & 0.04 \\
1980 & $18-33$ & 2.49 & 1.92 & 0.57 & 0.42 & 0.38 & 0.04 \\
1981 & $18-34$ & 2.56 & 2.04 & 0.52 & 0.42 & 0.38 & 0.03 \\
1982 & $18-35$ & 3.03 & 2.45 & 0.57 & 0.51 & 0.47 & 0.03 \\
1983 & $18-36$ & 2.84 & 2.29 & 0.55 & 0.47 & 0.43 & 0.04 \\
1984 & $18-37$ & 2.83 & 2.31 & 0.52 & 0.47 & 0.44 & 0.03 \\
1985 & $18-38$ & 2.65 & 2.16 & 0.49 & 0.44 & 0.41 & 0.03 \\
1986 & $18-39$ & 2.29 & 1.82 & 0.47 & 0.39 & 0.36 & 0.03 \\
1987 & $18-40$ & 2.66 & 2.18 & 0.48 & 0.38 & 0.35 & 0.03 \\
1988 & $19-40$ & 2.33 & 1.83 & 0.50 & 0.35 & 0.32 & 0.04 \\
1989 & $20-40$ & 2.01 & 1.51 & 0.51 & 0.34 & 0.31 & 0.04 \\
1990 & $21-40$ & 1.86 & 1.39 & 0.47 & 0.32 & 0.29 & 0.04 \\
1991 & $22-40$ & 1.83 & 1.42 & 0.41 & 0.30 & 0.28 & 0.03 \\
1992 & $23-40$ & 1.67 & 1.31 & 0.36 & 0.28 & 0.25 & 0.03 \\
1993 & $24-40$ & 1.55 & 1.22 & 0.33 & 0.27 & 0.25 & 0.02 \\
1994 & $25-40$ & 1.38 & 1.08 & 0.30 & 0.28 & 0.26 & 0.02 \\
1995 & $26-40$ & 1.19 & 0.97 & 0.23 & 0.23 & 0.21 & 0.02 \\
1996 & $27-40$ & 1.14 & 0.93 & 0.21 & 0.22 & 0.20 & 0.02 \\
\hline
\end{tabular}

General Household Survey (GHS)

Our analysis uses GHS data from 1972 to 1996 . The survey took place on a calendar year basis from 1972 to 1987, and then moved to financial year. Using month of survey we matched the GHS to the OID for England and Wales by age and year on a calendar year basis.

\footnotetext{
${ }^{15}$ We do not consider sexual offences since there are very few of them and their relationship with education is contrary to that of other crimes (as in the case of rape in Lochner and Moretti, 2004).
} 
We use two education variables from GHS:

i) Age left school - variable AGELFTS from 1972-82 and AGELFTSC from 1983-96. Age left school is set to missing if less than 13 above 25 .

ii) No educational qualifications - derived from variables measuring highest educational qualification or whether individuals have any educational qualifications.

The school leaving age variable was constructed from year of birth as follows. The GHS contains actual year of birth from 1986-95. In other years, like Devereux and Hart (2010) we coded year of birth as (year of survey - age) in the July-December survey months and (year of survey - age -1) for the January-June survey months. The variable was coded to 0 for birth cohorts before 1957, to 0.33 in 1957 (as the law became binding in September 1972) and to 1 for birth cohorts from 1958 onwards.

We matched to the OID data by age and year for years 1972 to 1996 for people aged 1840 born between 1946 and 1970, eliminating discrepancies between age and year of birth.

The control variables were as follows: proportion employed; proportion living in London; proportion white; proportion British born.

The data structure for men and women, with means of the two education variables is as follows:

\begin{tabular}{lccccc}
\hline $\begin{array}{c}\text { GHS } \\
\text { Year }\end{array}$ & $\begin{array}{c}\text { Age } \\
\text { Range }\end{array}$ & $\begin{array}{c}\text { Men, No } \\
\text { Qualifications }\end{array}$ & $\begin{array}{c}\text { Men, Age } \\
\text { Left School }\end{array}$ & $\begin{array}{c}\text { Women, No } \\
\text { Qualifications }\end{array}$ & $\begin{array}{c}\text { Women, Age } \\
\text { Left School }\end{array}$ \\
\hline & & & & & \\
1972 & $18-26$ & 0.44 & 15.85 & 0.50 & 15.69 \\
1973 & $18-27$ & 0.36 & 15.76 & 0.46 & 15.69 \\
1974 & $18-28$ & 0.36 & 15.76 & 0.44 & 15.73 \\
1975 & $18-29$ & 0.35 & 15.76 & 0.45 & 15.72 \\
1976 & $18-30$ & 0.34 & 15.83 & 0.43 & 15.76 \\
1977 & $18-31$ & 0.32 & 16.00 & 0.40 & 15.87 \\
1978 & $18-32$ & 0.30 & 16.03 & 0.40 & 15.95 \\
1979 & $18-33$ & 0.32 & 16.01 & 0.37 & 15.97 \\
1980 & $18-34$ & 0.29 & 16.08 & 0.37 & 16.01
\end{tabular}




\begin{tabular}{llllll}
1981 & $18-35$ & 0.30 & 16.07 & 0.37 & 16.02 \\
1982 & $18-36$ & 0.29 & 16.10 & 0.33 & 16.04 \\
1983 & $18-37$ & 0.28 & 16.10 & 0.33 & 16.02 \\
1984 & $18-38$ & 0.28 & 16.06 & 0.34 & 16.01 \\
1985 & $18-39$ & 0.28 & 16.10 & 0.32 & 16.03 \\
1986 & $18-40$ & 0.26 & 16.06 & 0.32 & 16.02 \\
1987 & $18-40$ & 0.25 & 16.12 & 0.29 & 16.07 \\
1988 & $18-40$ & 0.21 & 16.27 & 0.23 & 16.22 \\
1989 & $18-40$ & 0.20 & 16.28 & 0.23 & 16.24 \\
1990 & $19-40$ & 0.20 & 16.28 & 0.24 & 16.25 \\
1991 & $20-40$ & 0.20 & 16.31 & 0.21 & 16.26 \\
1992 & $21-40$ & 0.17 & 16.34 & 0.18 & 16.31 \\
1993 & $22-40$ & 0.16 & 16.41 & 0.18 & 16.36 \\
1994 & $23-40$ & 0.14 & 16.40 & 0.18 & 16.37 \\
1995 & $24-40$ & 0.16 & 16.37 & 0.17 & 16.37 \\
1996 & $25-40$ & 0.15 & 16.38 & 0.17 & 16.36 \\
\hline
\end{tabular}




\section{Appendix B}

Table B1: The Causal Effect of Education on Crime, by Broad Types of Crime, Women

Women, Aged 18-40, Born 1946-70, Discontinuity Sample

\begin{tabular}{|c|c|c|c|c|c|c|c|c|c|c|}
\hline \multirow{3}{*}{ A. Population Weighted } & \multicolumn{5}{|c|}{ Log(Property Convictions per 1000 Population) } & \multicolumn{5}{|c|}{ Log(Violent Convictions per 1000 Population) } \\
\hline & \multicolumn{3}{|c|}{ No Qualifications } & \multicolumn{2}{|c|}{ Age Left School } & \multicolumn{3}{|c|}{ No Qualifications } & \multicolumn{2}{|c|}{ Age Left School } \\
\hline & $\begin{array}{c}(1) \\
\text { Crime } \\
\text { Reduced } \\
\text { Form }\end{array}$ & $\begin{array}{c}(2) \\
\text { Education } \\
\text { Reduced } \\
\text { Form }\end{array}$ & $\begin{array}{c}(3) \\
\text { Crime } \\
\text { Structural } \\
\text { Form }\end{array}$ & $\begin{array}{c}\text { (4) } \\
\text { Education } \\
\text { Reduced } \\
\text { Form }\end{array}$ & $\begin{array}{c}(5) \\
\text { Crime } \\
\text { Structural } \\
\text { Form }\end{array}$ & $\begin{array}{c}(6) \\
\text { Crime } \\
\text { Reduced } \\
\text { Form }\end{array}$ & $\begin{array}{c}(7) \\
\text { Education } \\
\text { Reduced } \\
\text { Form }\end{array}$ & $\begin{array}{c}(8) \\
\text { Crime } \\
\text { Structural } \\
\text { Form }\end{array}$ & $\begin{array}{c}(9) \\
\text { Education } \\
\text { Reduced } \\
\text { Form }\end{array}$ & $\begin{array}{c}(10) \\
\text { Crime } \\
\text { Structural } \\
\text { Form }\end{array}$ \\
\hline School Leaving Age Increase & $\begin{array}{c}-0.017 \\
(0.064)\end{array}$ & $\begin{array}{c}-0.168 \\
(0.019)\end{array}$ & & $\begin{array}{c}0.363 \\
(0.038)\end{array}$ & & $\begin{array}{c}-0.261 \\
(0.263)\end{array}$ & $\begin{array}{c}-0.168 \\
(0.019)\end{array}$ & & $\begin{array}{c}0.363 \\
(0.038)\end{array}$ & \\
\hline No Qualifications & & & $\begin{array}{c}0.106 \\
(0.382)\end{array}$ & & & & & $\begin{array}{c}1.557 \\
(1.594)\end{array}$ & & \\
\hline Age Left School & & & & & $\begin{array}{c}-0.049 \\
(0.177)\end{array}$ & & & & & $\begin{array}{c}-0.719 \\
(0.740)\end{array}$ \\
\hline F-test & $\begin{array}{c}\mathrm{F}(1,117) \\
=0.08 \\
{[\mathrm{P}=.781]}\end{array}$ & $\begin{array}{c}\mathrm{F}(1,117) \\
=80.27 \\
{[\mathrm{P}=.000]}\end{array}$ & & $\begin{array}{c}\mathrm{F}(1,117) \\
=89.20 \\
{[\mathrm{P}=.000]}\end{array}$ & & $\begin{array}{c}\mathrm{F}(1,117) \\
=0.98 \\
{[\mathrm{P}=.324]}\end{array}$ & $\begin{array}{c}\mathrm{F}(1,117) \\
=80.27 \\
{[\mathrm{P}=.000]}\end{array}$ & & $\begin{array}{c}\mathrm{F}(1,117) \\
=89.20 \\
{[\mathrm{P}=.000]}\end{array}$ & \\
\hline B. Inverse Distance Weighted & & \multicolumn{2}{|c|}{ No Qualifications } & \multicolumn{2}{|c|}{ Age Left School } & & \multicolumn{2}{|c|}{ No Qualifications } & \multicolumn{2}{|c|}{ Age Left School } \\
\hline & $\begin{array}{c}(1) \\
\text { Crime } \\
\text { Reduced } \\
\text { Form }\end{array}$ & $\begin{array}{c}\text { (2) } \\
\text { Education } \\
\text { Reduced } \\
\text { Form }\end{array}$ & $\begin{array}{c}\text { (3) } \\
\text { Crime } \\
\text { Structural } \\
\text { Form }\end{array}$ & $\begin{array}{c}\text { (4) } \\
\text { Education } \\
\text { Reduced } \\
\text { Form }\end{array}$ & $\begin{array}{c}(5) \\
\text { Crime } \\
\text { Structural } \\
\text { Form } \\
\end{array}$ & $\begin{array}{c}(6) \\
\text { Crime } \\
\text { Reduced } \\
\text { Form }\end{array}$ & $\begin{array}{c}\text { (7) } \\
\text { Education } \\
\text { Reduced } \\
\text { Form }\end{array}$ & $\begin{array}{c}(8) \\
\text { Crime } \\
\text { Structural } \\
\text { Form }\end{array}$ & $\begin{array}{c}\text { (4) } \\
\text { Education } \\
\text { Reduced } \\
\text { Form }\end{array}$ & $\begin{array}{c}(10) \\
\text { Crime } \\
\text { Structural } \\
\text { Form }\end{array}$ \\
\hline School Leaving Age Increase & $\begin{array}{c}-0.017 \\
(0.063)\end{array}$ & $\begin{array}{c}-0.185 \\
(0.019)\end{array}$ & & $\begin{array}{c}0.430 \\
(0.039)\end{array}$ & & $\begin{array}{c}-0.242 \\
(0.267)\end{array}$ & $\begin{array}{c}-0.185 \\
(0.019)\end{array}$ & & $\begin{array}{c}0.430 \\
(0.039)\end{array}$ & \\
\hline No Qualifications & & & $\begin{array}{c}0.092 \\
(0.338)\end{array}$ & & & & & $\begin{array}{c}1.311 \\
(1.461)\end{array}$ & & \\
\hline Age Left School & & & & & $\begin{array}{l}-0.039 \\
(0.146)\end{array}$ & & & & & $\begin{array}{l}-0.563 \\
(0.632)\end{array}$ \\
\hline F-test & $\begin{array}{c}\mathrm{F}(1,117) \\
=0.07 \\
{[\mathrm{P}=.787]}\end{array}$ & $\begin{array}{c}\mathrm{F}(1,117) \\
=92.73 \\
{[\mathrm{P}=.000]}\end{array}$ & & $\begin{array}{l}\mathrm{F}(1,117) \\
=120.79 \\
{[\mathrm{P}=.000]}\end{array}$ & & $\begin{array}{c}\mathrm{F}(1,117) \\
=0.82 \\
{[\mathrm{P}=.366]}\end{array}$ & $\begin{array}{c}\mathrm{F}(1,117) \\
=92.73 \\
{[\mathrm{P}=.000]}\end{array}$ & & $\begin{array}{l}\mathrm{F}(1,117) \\
=120.79 \\
{[\mathrm{P}=.000]}\end{array}$ & \\
\hline
\end{tabular}

Notes: As for Table 2. All specifications include a full set of age and year dummies and control variables. Sample size is 169 in all cases. 